\title{
Impacts of climatic variables on cyclone in the coastal regions of Bangladesh
}

\author{
MAM Hossen*, MA Farukh, MS Hossen, MA Badhan, S Biswas, MA Rahman
}

Department of Environmental Science, Bangladesh Agricultural University, Mymensingh 2202, Bangladesh

\begin{abstract}
Geographical position of Bangladesh makes it vulnerable to several extreme weather events like cyclone in the southern part due to extreme climatological events. Therefore, in this study, we had mainly tried to study on the variations of temperature, relative humidity $(\mathrm{RH})$ and sunshine hours $(\mathrm{SH})$ in the coastal areas to find out its effect on the formation of cyclone. Data from 1975-2014 of these climatic variables was provided by the Bangladesh Meteorological Department (BMD) and analyzed with the statistical tool MS Excel 2010 as per objective of the study. Results showed that in the 16 stations, temperature has shown homogenous trend where it has seen that in all the stations the $\mathrm{T}_{\text {mean }}$ and $\mathrm{T}_{\max }$ were ranging from $18^{\circ} \mathrm{C}$ to $30^{\circ} \mathrm{C}$ and $28^{\circ} \mathrm{C}$ to $42^{\circ} \mathrm{C}$ respectively. In maximum stations, the $\mathrm{T}_{\max }$ and extreme $\mathrm{T}_{\text {mean }}$ has found in the months of April and May which is a cyclone occurring month. Again $\mathrm{RH}_{\max }$ has mostly found in the post monsoon season where $\mathrm{RH}_{\text {mean }}$ is ranging $84 \sim 88 \%$ mainly in the Khulna, Mongla, Khepupara and Barisal areas, may have profound influence on the formation of cyclone especially in this area. $\mathrm{SH}_{\max }$ has found in the month April where the highest was about $12.08 \mathrm{hr}$. These higher amounts of temperature play profound influence in increasing temperature in the studied areas which have direct consequences on cyclone events. So, extreme temperature, RH and SH in these months may had profound influence on the formation of cyclone. These information could be very useful to the related scientists to study on several extreme weather events due to variation of temperature especially on cyclogenesis which are a most common devastating phenomenon for the coastal areas like Bangladesh.
\end{abstract}

Key words: Extreme weather, climatic variables, variation of temperature, cyclogenesis

Progressive Agriculturists. All rights reserve

*Corresponding Author: musabbir.esrm@gmail.com

\section{Introduction}

Bangladesh is a low-lying country located in the deltaic plain of the Ganges, the Brahmaputra and the Meghna and densely populated. Its national economy strongly depends on agriculture and natural resources that are sensitive to climate change. The impact of higher temperature and more extreme weather events such as floods, cyclone, severe drought and sea level rise are already being felt in south Asia and will continue to intensify (Huq et al., 1999; Ali, 1999). In this connection proper planning and analyses of climatic variations with their extreme events are essential to find out for this area. The southern region mainly known as a coastal region of Bangladesh experiences cyclone almost every year. As found from the statistics that, changes in temperature played a great role to cause such cyclone events in the southern coastal region. Cyclones originate from deep depression which is a consequence of high amount of temperature in the coastal region which is quite common in Bangladesh. They generally occur in early summer of the month from April-May or late rainy season from NovemberDecember (Choudhury, 1992; Wisner et al., 2004; Ali, 
1999; Paul, 2009; Farukh and Baten, 2015). For the formation of cyclone the effective temperature is about 27 to $29^{\circ} \mathrm{C}$ which is responsible for category 1 to category 5 cyclone in the context of Bangladesh (Kumar et al., 2011; Khan, 2012). So, it can be said that any temperature within or above of range would trigger the formation of a cyclone. Relative humidity $(\mathrm{RH})$ is another important climatic factor and is also responsible for the formation of any kind of unsteady condition. Study on this parameter is also important because temperature and $\mathrm{RH}$ relates to each other (Lawrence, 2004; Skilling, 2009) and RH has a good influence on the formation of cyclone (Kaplan and DeMaria, 2003; Emanuel et al., 2004; Hendricks et al., 2010; Kaplan et al., 2010). Wu et al. (2012) showed that about $82 \% \mathrm{RH}$ is responsible for the occurrence of North Atlantic Tropical cyclone. So, RH above this level is very much responsible for the formation of cyclone in the coastal region of Bangladesh. There are some indirect consequences of the Sunshine hours (SH) also, because SH have positive relationship with the temperature (Matuszko and Weglerczyk, 2014), and temperature has direct effect on the formation of cyclone. As a result, there is an increasing research interest in different parts of the world as well as in Bangladesh on extreme climatic parameters and their variations. Keeping these things in mind, the present study was therefore undertaken to find out the variability of temperature, $\mathrm{RH}$ and $\mathrm{SH}$ in terms of cyclone events in the coastal region of Bangladesh.

\section{Materials and Methods}

\section{Study Area}

The coastal area of Bangladesh surrounding the BB was selected as the study area. Satkhira, Khulna, Mongla, Khepupara, Barishal, Bhola, Patuakhali, Hatiya, Chandpur, Feni, Sandwip, Sitakunda, Chittagong, Kutubdia, Cox's Bazar and Teknaf was our study area.

\section{Weather Data}

In this study, daily weather data of temperature, sunshine hours $(\mathrm{SH})$ and relative humidity $(\mathrm{RH})$ were analyzed which were obtained from Bangladesh Meteorological Department, Agargaon, Dhaka, Bangladesh. The collected data were three hourly daily temperature $\left({ }^{0} \mathrm{C}\right)$, average air temperature $\left({ }^{0} \mathrm{C}\right)$, maximum air temperature $\left({ }^{0} \mathrm{C}\right)$, minimum air temperature $\left({ }^{\circ} \mathrm{C}\right)$, three hourly relative humidity $(\%)$ and sunshine hours (hr.). To compare the parameter, weather data from the indicated stations were carefully analyzed.

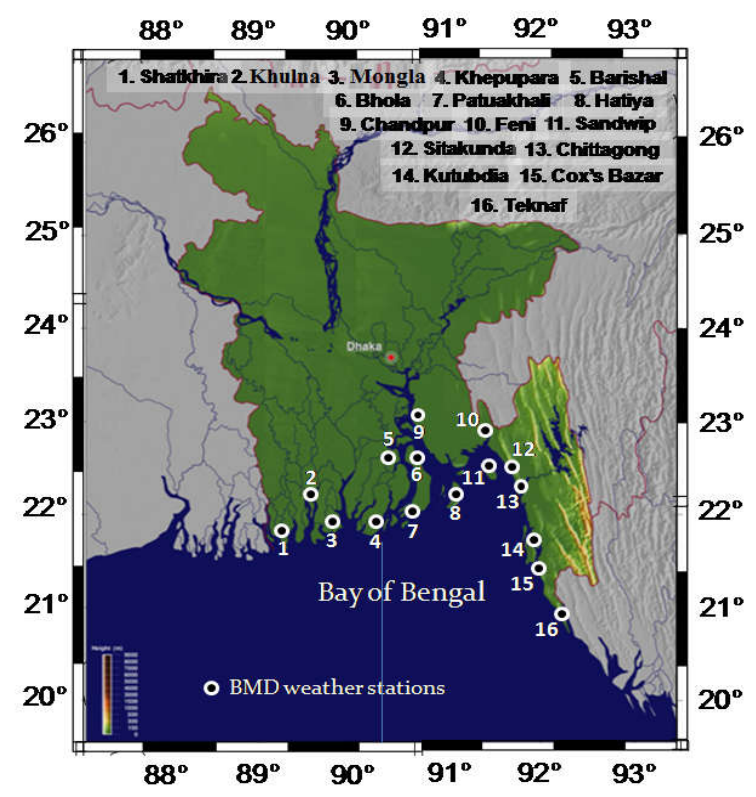

Figure 1. GIS plotting of 16 stations in southern coastal regions of Bangladesh

\section{Data Processing and Analyses}

All the collected data were then compiled, tabulated, and analyzed according to the objectives of the study. Daily average air temperature $\left({ }^{0} \mathrm{C}\right)$, maximum air temperature $\left({ }^{0} \mathrm{C}\right)$, minimum air temperature $\left({ }^{0} \mathrm{C}\right)$, three hourly relative humidity (\%) and sunshine hours (hr.) were calculated using frequently used statistical software Minitab and MS Excel 2010 to analyze the variation and trend lines. The box plotting shows in the 
figure expose the long term mean, mean+SD and mean-SD of temperature, $\mathrm{RH}$ and $\mathrm{SH}$ in these regions. The line through the box plot indicating the mean value of temperature, RH and SH. Upper portion of the box shows the mean $+\mathrm{SD}$ and the lower portion of the box shows the mean-SD value. The red, blue and red markers in the three types of graph represent the maximum temperature, $\mathrm{RH}$ and $\mathrm{SH}$ while the purple, green and blue markers represent the minimum temperature, $\mathrm{RH}$ and $\mathrm{SH}$ respectively in the definite area. In the results and discussion part few stations has discussed among the 16 stations based on mostly affected areas of cyclone from 1975-2014 showed in Table 1.

Table 1. List of Cyclone Events in Bangladesh from 1975-2014

\begin{tabular}{|c|c|c|c|c|}
\hline Year & $\begin{array}{l}\text { Date and } \\
\text { Month }\end{array}$ & Affected Area & Nature of the phenomenon & Approximate loss \\
\hline 1975 & $\begin{array}{l}\text { May } \\
9-12\end{array}$ & $\begin{array}{l}\text { Sunderban-Bhola- } \\
\text { Chittagong coast }\end{array}$ & $\begin{array}{l}\text { Severe cyclonic storm, } \mathrm{w}=110 \\
\mathrm{~km} / \mathrm{h} \text {. }\end{array}$ & 5 people killed \\
\hline 1976 & $\begin{array}{l}\text { October } \\
19-20\end{array}$ & Meghna estuary & $\begin{array}{l}\text { Severe Cyclonic storm, } \mathrm{w}=105 \\
\mathrm{~km} / \mathrm{h} \text {, tide plus surge at } \\
\text { Companygonj was } 3.5 \mathrm{~m} .\end{array}$ & Damage data not available \\
\hline 1977 & $\begin{array}{l}\text { May } \\
9-12\end{array}$ & $\begin{array}{l}\text { Sunderban-chittagong } \\
\text { coast (landfall at } \\
\text { Sunderban) }\end{array}$ & $\begin{array}{l}\text { Cyclonic storm, } \mathrm{w}=113 \mathrm{~km} / \mathrm{h} \text {, } \\
\mathrm{s}=0.6 \mathrm{~m} \text { and } \mathrm{t}=0.7 \mathrm{~m} .\end{array}$ & Damage data not available \\
\hline 1978 & $\begin{array}{l}\text { September } \\
30 \text { to } \\
\text { October } 3 \\
\end{array}$ & $\begin{array}{l}\text { Sunderban khulna } \\
\text { coast }\end{array}$ & Cyclonic storm, $\mathrm{w}=74 \mathrm{~km} / \mathrm{h}$. & Damage data not available \\
\hline \multirow[b]{2}{*}{1983} & 15-Oct & $\begin{array}{lr}\text { Chittagong-Feni } & \text { coast } \\
\text { (landfall near } \\
\text { Chittagong) }\end{array}$ & $\begin{array}{l}\text { Severe Cyclonic storm, } \mathrm{w}=122 \\
\mathrm{~km} / \mathrm{h} \text {. }\end{array}$ & $\begin{array}{l}43 \text { persons were killed, } 1000 \\
\text { fishermen missing and } 20 \% \text { aman } \\
\text { crops destroyed }\end{array}$ \\
\hline & November 9 & $\begin{array}{l}\text { Chittagong-Teknaf } \\
\text { coast (landfall } \\
\text { between } \\
\text { Chittagong and Cox's } \\
\text { Bazar) }\end{array}$ & $\begin{array}{l}\text { Severe cyclonic storm, } \mathrm{w}=136 \\
\mathrm{~km} / \mathrm{h}\end{array}$ & $\begin{array}{l}300 \text { fishermen with } 50 \text { boats } \\
\text { missing; } 2000 \\
\text { institutions destroyed }\end{array}$ \\
\hline 1985 & May $24-25$ & $\begin{array}{l}\text { Noakhali-Cox's Bazar } \\
\text { coast (landfall at } \\
\text { Sandwip) }\end{array}$ & $\begin{array}{l}\text { Severe cyclonic storm, } \mathrm{w}=154 \\
\mathrm{~km} / \mathrm{h}\end{array}$ & $\begin{array}{l}\text { 11,069 people killed, } 94,379 \text { houses } \\
\text { damaged,64 km road and } 390 \mathrm{~km} \\
\text { embankment damaged }\end{array}$ \\
\hline 1986 & 9-Nov & $\begin{array}{l}\text { Barguna-Chittagong } \\
\text { coast }\end{array}$ & $\begin{array}{l}\text { Severe Cyclonic storm, } \mathrm{w}=110 \\
\mathrm{~km} / \mathrm{h} \text {. }\end{array}$ & $\begin{array}{l}14 \text { lives lost and huge damage to } \\
\text { crops and properties }\end{array}$ \\
\hline 1988 & 29-Nov & Sunderban & $\begin{array}{l}\text { Severe cyclonic storm, } \mathrm{w}=160 \\
\mathrm{~km} / \mathrm{h}\end{array}$ & $\begin{array}{l}5,708 \text { people killed and } 6,000 \\
\text { missing; } 65,000 \text { cattle were lost }\end{array}$ \\
\hline 1990 & October $7-8$ & $\begin{array}{l}\text { Barguna-Noakhali } \\
\text { coast }\end{array}$ & Cyclonic storm & $\begin{array}{l}150 \text { fishermen with } 16 \text { mechanised } \\
\text { boats missing }\end{array}$ \\
\hline \multirow[b]{2}{*}{1991} & 29-Apr & $\begin{array}{l}\text { Patuakhali-Cox's } \\
\text { Bazar coast (landfall } \\
\text { north of Chittagong) }\end{array}$ & $\begin{array}{l}\text { Most severe cyclonic storm, } \\
\mathrm{w}=235 \mathrm{~km} / \mathrm{h}\end{array}$ & $\begin{array}{l}145,000 \text { people killed, } 70,000 \text { cattle } \\
\text { killed, crops were damaged }\end{array}$ \\
\hline & $\begin{array}{l}\text { May } 31 \\
\text { to June } 2\end{array}$ & $\begin{array}{l}\text { Offshore islands and } \\
\text { chars of Patuakhali, } \\
\text { Barisal, Noakhali and } \\
\text { Chittagong }\end{array}$ & $\begin{array}{l}\text { Severe cyclonic storm, maximum } \\
\mathrm{w}=110 \mathrm{~km} / \mathrm{hr}\end{array}$ & $\begin{array}{l}\text { People killed, cattlehead perished, } \\
\text { boats lost and standing crops } \\
\text { destroyed. }\end{array}$ \\
\hline 1994 & $\begin{array}{l}\text { April } 29 \\
\text { to May } 3\end{array}$ & $\begin{array}{l}\text { Offshore island and } \\
\text { chars of Cox's Bazar }\end{array}$ & $\begin{array}{l}\text { Severe cyclonic storm with } \\
\text { maximum wind speed of } 210 \\
\mathrm{~km} / \mathrm{hr}\end{array}$ & $\begin{array}{l}\text { People killed about } 400 \text {, cattle lost } \\
\text { about } 8,000\end{array}$ \\
\hline 1995 & $\begin{array}{l}\text { November } \\
21-25\end{array}$ & $\begin{array}{l}\text { Offshore island and } \\
\text { chars of Cox's Bazar }\end{array}$ & $\begin{array}{l}\text { Severe cyclonic storm with } \\
\text { maximum wind speed of } 210 \\
\mathrm{~km} / \mathrm{hr}\end{array}$ & $\begin{array}{l}\text { About } 650 \text { people killed, } 17,000 \\
\text { cattlehead perished. }\end{array}$ \\
\hline
\end{tabular}


Table 1. List of Cyclone Events in Bangladesh from 1975-2014 (-Contd.-)

\begin{tabular}{|c|c|c|c|c|}
\hline Year & $\begin{array}{l}\text { Date and } \\
\text { Month }\end{array}$ & Affected Area & Nature of the phenomenon & Approximate loss \\
\hline \multirow{2}{*}{1997} & May 16-19 & $\begin{array}{l}\text { Offshore islands and } \\
\text { chars of Chittagong, } \\
\text { Cox's Bazar, Noakhali } \\
\text { and Bhola }\end{array}$ & $\begin{array}{l}\text { Severe cyclonic storm (hurricane) } \\
\text { with a wind speed of } 225 \mathrm{~km} / \mathrm{hr} \text {, } \\
\text { storm surge of } 3.05 \mathrm{~m}\end{array}$ & $\begin{array}{l}\text { Only } 126 \text { people killed because of } \\
\text { better disaster management } \\
\text { measures taken by the government } \\
\text { and the people. }\end{array}$ \\
\hline & $\begin{array}{l}\text { September } \\
25-27\end{array}$ & $\begin{array}{l}\text { Offshore islands and } \\
\text { chars of Chittagong, } \\
\text { Cox's Bazar, Noakhali } \\
\text { and Bhola }\end{array}$ & $\begin{array}{l}\text { Severe cyclonic storm (hurricane) } \\
\text { with a wind speed of } 150 \mathrm{~km} / \mathrm{hr} \text {, } \\
\text { storm surge of } 1.83 \text { to } 3.05 \mathrm{~m} \text {. }\end{array}$ & Damage data not available \\
\hline \multirow{2}{*}{1998} & May 16-20 & $\begin{array}{l}\text { Offshore islands and } \\
\text { chars of Chittagong, } \\
\text { Cox's Bazar and } \\
\text { Noakhali }\end{array}$ & $\begin{array}{l}\text { Severe cyclonic storm (hurricane) } \\
\text { with a wind speed of } 150 \mathrm{~km} / \mathrm{hr} \text {, } \\
\text { storm surge of } 1.83 \text { to } 2.44 \mathrm{~m} \text {. }\end{array}$ & Damage data not available \\
\hline & $\begin{array}{l}\text { November } \\
19-22\end{array}$ & $\begin{array}{l}\text { Offshore islands and } \\
\text { chars of Khulna, } \\
\text { Barisal and Patuakhali }\end{array}$ & $\begin{array}{l}\text { Cyclonic storm with maximum } \\
\text { wind speed of } 90 \mathrm{~km} / \mathrm{hr} \text {, storm } \\
\text { surge of } 1.22 \text { to } 2.44 \mathrm{~m} .\end{array}$ & Damage data not available \\
\hline \multirow{2}{*}{2007} & May 14-15 & south of Chittagong & $\begin{array}{l}\text { Severe cyclone Akash struck with } \\
\text { wind speeds up to } 120 \mathrm{~km} / \text { hour }\end{array}$ & $\begin{array}{l}14 \text { people were killed and damages } \\
\text { amounted to US } \$ 982 \text { million. }\end{array}$ \\
\hline & 15-Nov & southern Bangladesh & $\begin{array}{l}\text { Severe cyclone Sidr with wind } \\
\text { speeds up to } 260 \mathrm{~km} / \text { hour }\end{array}$ & $\begin{array}{l}\text { Causing over } 3,500 \text { deaths and } \\
\text { severe damage. }\end{array}$ \\
\hline 2008 & $\begin{array}{l}\text { October 26- } \\
27\end{array}$ & Bangladesh coast & $\begin{array}{l}\text { Cyclone Rashmi with wind } \\
\text { speeds up to } 85 \mathrm{~km} / \text { hour }\end{array}$ & $\begin{array}{l}15 \text { people were killed and } \\
\text { thousands of homes were also } \\
\text { damaged. }\end{array}$ \\
\hline \multirow{2}{*}{2009} & April 19-21 & Bangladesh coast & Cyclone Bijli & $\begin{array}{l}\text { not so severe damages were } \\
\text { recorded except some houses and } \\
\text { crop fields losses }\end{array}$ \\
\hline & May 27-29 & $\begin{array}{l}15 \text { districts of south- } \\
\text { western part of } \\
\text { Bangladesh }\end{array}$ & $\begin{array}{l}\text { Severe Cyclone Aila with wind } \\
\text { speeds up to } 120 \mathrm{~km} / \mathrm{hour}\end{array}$ & $\begin{array}{l}\text { About } 150 \text { persons killed, } 2 \text { lac } \\
\text { houses and } 3 \text { lac acres of cultivated } \\
\text { land and crops losses. }\end{array}$ \\
\hline 2013 & May 16-17 & Chittagong & $\begin{array}{l}\text { Cyclonic Storm Mahasen with } \\
\text { wind speeds up to } 85 \mathrm{~km} / \text { hour }\end{array}$ & $\begin{array}{l}17 \text { people died, and nearly } 1.3 \\
\text { million were affected across the } \\
\text { country. Losses to crops exceeded } \\
\text { US } \$ 5.14 \text { million. }\end{array}$ \\
\hline
\end{tabular}

\section{Results and Discussions}

The statistics of the 9 stations and the ensemble means of the 16 stations has represented and discussed in this chapter. Temperature $\left({ }^{0} \mathrm{C}\right), \mathrm{RH}(\%)$ and $\mathrm{SH}$ (hr.) of the 9 stations have represented where the figures are drawn by using the raw data from the year of 1975 to 2014 and the discussion have made based on the two cyclone occurring period from March to June and from September to November (Farukh and Baten, 2015).

\section{Satkhira}

Mean air temperature $\left(\mathrm{T}_{\text {mean }}\right)$, maximum air temperature $\left(T_{\max }\right)$, minimum air temperature $\left(T_{\min }\right)$ and mean \pm SD of Satkhira from 1975 to 2014 is shown in Figure 2 (a). The extreme $T_{\max }$ of Satkhira is found in the month of May $\left(38.10^{\circ} \mathrm{C}\right)$ where the highest $\mathrm{T}_{\text {mean }}$ is $29.95^{\circ} \mathrm{C}$, both of which is in the cyclone occurring month May. The maximum temperature throughout the year ranges from $29^{\circ} \mathrm{C}$ to $38^{\circ} \mathrm{C}$ which is high enough to create unstable condition in the surrounding area. Mean $\mathrm{RH}\left(\mathrm{RH}_{\text {mean }}\right)$, maximum $\mathrm{RH}\left(\mathrm{RH}_{\max }\right)$, minimum $\mathrm{RH}$ $\left(\mathrm{RH}_{\min }\right)$ and mean $\pm \mathrm{SD}$ have shown in the Figure 2(b). The $\mathrm{RH}_{\max }$ in Satkhira area is seen in August and September (99\%) where their mean is around $86 \%$. Again in April and May, the $\mathrm{RH}_{\max }$ was $98 \%$ and the $\mathrm{RH}_{\max }$ throughout the whole year ranged from 98-99\% which indicated hot and humid situation on that 
particular month. The higher RH also indicates higher temperature. Both of the parameters together may create any unsteady situation. Again, the highest RH range in this area indicates powerful signal of cyclogenesis. SH have shown the reverse trend compared to temperature and $\mathrm{RH}$. The trend is shown in the Figure 2(c) where the highest period of $\mathrm{SH}$ $\left(\mathrm{SH}_{\max }\right)$ in this region was in the month of April (11.30 hr.). From the figure, it is clearly seen that the maximum mean of $\mathrm{SH}\left(\mathrm{SH}_{\text {mean }}\right)$ was in April which is more than 8.5 hours. The longest period of SH in April may have a strong influence in uprising of temperature which in consequence may form any cyclonic event in Satkhira region.

\section{Khulna}

For Khulna region, temperature $\left({ }^{0} \mathrm{C}\right)$ has shown in the Figure 2(d). From the figure, it has shown that temperature in this region in same trend like it was in Satkhira. Here, $\mathrm{T}_{\max }$ is $37.56^{\circ} \mathrm{C}$ that has found in the month of April and the highest mean value is about $29.5^{\circ} \mathrm{C}$ which is in the month of May. These two months (April and May) indicated the $\mathrm{T}_{\max }$ and highest mean value respectively are known as the cyclone occurring month. The $\mathrm{T}_{\max }$ ranges throughout the year is about $29^{\circ} \mathrm{C}$ to $37.5^{\circ} \mathrm{C}$ which is very high amount and favorable for creating unstable disorder in the surrounding area which later may form deep depression and cause shattering cyclone. $\mathrm{RH}_{\max }, \mathrm{RH}_{\text {min }}, \mathrm{RH}_{\text {mean }}$ and mean $\pm \mathrm{SD}$ of $\mathrm{RH}$ in Khulna area has shown in the Figure 2(e) where $\mathrm{RH}_{\text {mean }}$ in Khulna area is uppermost in the month of September pointing about $89 \%$ and the highest value throughout the year ranging from $98-99 \%$ and any area within this range indicated how hot and humid it was on that certain day. These high amounts of $\mathrm{RH}$ also indicate great amount of temperature on such day both of which may responsible for creating any unsteady situation which in later may cause some extreme events. The highest range in this area is a strong indicator for the formation of cyclone. The trend of SH in this region has shown in the Figure 2(f) where the $\mathrm{SH}_{\max }$ in this region is in the month of April (12.08 hr.). The maximum mean has also found in the month of April pointing at $8.5 \mathrm{hr}$. This highest amount of SH also indicating higher amount of temperature in April at Khulna. This higher amount of temperature may create deep depression and form cyclonic activity in this area.

\section{Mongla}

Temperature in $\left({ }^{0} \mathrm{C}\right)$ has shown in the Figure $2(\mathrm{~g})$ where extreme $\mathrm{T}_{\max }$ has shown in the month of April which is about $37.62^{\circ} \mathrm{C}$ and the highest of $\mathrm{T}_{\text {mean }}$ has found in the month of May $\left(29.84^{\circ} \mathrm{C}\right)$. From August to October, the $\mathrm{T}_{\text {mean }}$ is ranging from 27.5 to $28.5^{\circ} \mathrm{C}$ where the $\mathrm{T}_{\max }$ has found about $34.5^{\circ} \mathrm{C}$. Again the range of $\mathrm{T}_{\max }$ throughout the year is about $29-38^{\circ} \mathrm{C}$. So, these maximum values indicating strong possibilities for unstable weather conditions in the studied area. Difference of maximum temperature from the mean is about $5-10^{\circ} \mathrm{C}$ which sudden rise may cause any extreme weather events like cyclone in this area. $\mathrm{RH}_{\text {max }}, \mathrm{RH}_{\text {min }}, \mathrm{RH}_{\text {mean }}$ and mean $\pm \mathrm{SD}$ has shown in the Figure 2(h) where the $\mathrm{RH}_{\max }$ in this region has shown in the month of September, November, January and March (99.92\%). So, trend of RH of Mongla region is little bit different from the stations of Satkhira and Khulna. The highest $\mathrm{RH}_{\text {mean }}$ is about $89 \%$ in the month of September which indicated hot and humid circumstances in that specific month in Mongla. September is also known as the cyclonic month and this high amount of RH also may cause shaky condition in the specific area which may turn into deep depression later and ultimately forms cyclone.SH in this region has shown in the Figure 2(i). which shown that the $\mathrm{SH}_{\max }$ in this region is in the month of May which is about $12.13 \mathrm{hr}$. From the figure, it has found that the maximum of $\mathrm{SH}_{\text {mean }}$ is in the month of April (8.75 hr.). This maximum of $\mathrm{SH}_{\text {mean }}$ in April and the $\mathrm{SH}_{\max }$ in May in a day may have a strong influence in uprising of temperature which significantly may form any cyclonic event in Mongla region.

\section{Khepupara}

$\mathrm{T}_{\text {mean }}, \mathrm{T}_{\max }, \mathrm{T}_{\min }$ and mean $\pm \mathrm{SD}$ of temperature has shown in the Figure 2(j). In this area, $T_{\max }$ has shown in 
the month of April $\left(35.08^{0} \mathrm{C}\right)$ and the range of $\mathrm{T}_{\max }$ in this area throughout the year is about 29 to $35^{\circ} \mathrm{C}$ where the highest $\mathrm{T}_{\text {mean }}$ is about $30^{\circ} \mathrm{C}$ which is in the month of May. The high amount of temperature in the premonsoon period (April and May) indicating unstable condition at the surrounding area. Again the difference between the highest temperature and the higher mean value is about $5-8^{0} \mathrm{C}$ which also indicating the strong positive signals of increasing temperature. The trend of $\mathrm{RH}$ in Khepupara area has shown in the Figure 2(k) where $\mathrm{RH}_{\text {max }}, \mathrm{RH}_{\text {min }}, \mathrm{RH}_{\text {mean }}$ and mean $\pm \mathrm{SD}$ have represented. July has represented the highest $\mathrm{RH}_{\text {mean }}$ $(88.56 \%)$. In fact, from June to October the $\mathrm{RH}_{\text {mean }}$ is more than $85 \%$. These highest $\mathrm{RH}_{\text {mean }}$ in the area indicated hot and humid conditions in that specific months in Khepupara. September and October is also known as the cyclonic month and the high amount of $\mathrm{RH}$ showed in the figure also may cause insecure disorder in the specific area which in later may form deep depression and ultimately forms cyclone. The trend of $\mathrm{SH}$ (hr.) in this location has shown in the Figure 2(1). The $\mathrm{SH}_{\max }$ in this location is in the period of April (11.68 hr.) and the highest $\mathrm{SH}_{\text {mean }}$ is about 8 hours which has also found in the month of April. The longest period of $\mathrm{SH}$ in this area indicating also higher amount of temperature in April at Khepupara. This higher amount of temperature may form also cyclonic activity in that area.

\section{Bhola}

The $T_{\max }$ of Bhola in the Figure 2(m). has shown in the month of May $\left(35.10^{\circ} \mathrm{C}\right)$ and the $\mathrm{T}_{\max }$ in this area is ranging from $28-35^{\circ} \mathrm{C}$ throughout the year. The $\mathrm{T}_{\text {mean }}$ in this area throughout the year is ranging from $18-28.5^{\circ} \mathrm{C}$ where the maximum $\mathrm{T}_{\text {mean }}$ is about $28.5^{\circ} \mathrm{C}$ is in the month of May. So, the $\mathrm{T}_{\max }$ in this area has strong influence in creating unstable condition and also shows powerful indication for the formation of cyclone by creating low atmospheric pressure in the adjacent area. The abrupt $7-10^{\circ} \mathrm{C}$ difference of the temperature between the maximum range and the mean value are strong indication of changing temperature in the area in such a day where the condition of the environment may become unstable. RH of Bhola has given in the Figure 2(n). July has represented the $\mathrm{RH}_{\max }(99.97 \%)$ where the $\mathrm{RH}_{\text {mean }}$ is about $91 \%$. This highest mean value in the area indicated hot and humid circumstances in that specific month in Bhola. In both cyclone occurring months, the $\mathrm{RH}_{\text {mean }}$ is comparatively low and is not in at that level of forming cyclone though the maximum range is high enough in almost every month. The high amount of RH also may cause unstable condition in the specific area which in later may form deep depression and ultimately forms cyclone.SH of Bhola have given in the Figure 2(o). The $\mathrm{SH}_{\max }$ is $11.37 \mathrm{hr}$. has found in the month of April and the highest $\mathrm{SH}_{\text {mean }}$ is about 7 hours also found in the month of April. This highest level of $\mathrm{SH}$ also indicating higher amount of temperature in April at Bhola which may induce atmospheric low pressure in the area and may form cyclonic activity.

\section{Patuakhali}

$\mathrm{T}_{\text {mean }}, \mathrm{T}_{\max }, \mathrm{T}_{\min }$ and mean $\pm \mathrm{SD}$ of temperature have shown in the Figure 2(p). The $T_{\max }$ in this area is in the month of April $\left(35.96^{\circ} \mathrm{C}\right)$ and the $\mathrm{T}_{\text {mean }}$ is ranging throughout the year from $19-29^{\circ} \mathrm{C}$ where the maximum $\mathrm{T}_{\text {mean }}$ has found in the month of May which is a cyclone occurring month. Again, the $\mathrm{T}_{\max }$ in this region is ranging from $28-36^{\circ} \mathrm{C}$ throughout the year which is too high for creating any unstable condition on that day in the area. Again temperature above $28^{\circ} \mathrm{C}$ is vulnerable for occurring cyclone in the coastal region of Bangladesh in the cyclone occurring months. So, here the maximum temperature showing in the graph mainly in the two period of cyclone occurring months are strong enough to create any unstable condition which in later may generate deep depression in the surrounding area and as subsequent, cyclonic storm may form. RH from 1975-2014 of Patuakhali area has shown in the Figure 2(q). Like the other one, $\mathrm{RH}_{\max }$, $\mathrm{RH}_{\text {min }}, \mathrm{RH}_{\text {mean }}$ and mean $\pm \mathrm{SD}$ of $\mathrm{RH}$ also has shown here where July has represented the highest $\mathrm{RH}_{\text {mean }}$ pointing at $91 \%$. This highest mean value in the area 
indicated hot and humid circumstances in that specific month in Patuakhali. The high amount of RH also may cause insecure condition in the specific area which in later may form low atmospheric arc and ultimately forms cyclone. The Figure 2(r) has shown the SH for the area of Patuakhali where $\mathrm{SH}_{\max }, \mathrm{SH}_{\text {min }}, \mathrm{SH}_{\text {mean }}$ and mean $\pm \mathrm{SD}$ have shown in the figure. The $\mathrm{SH}_{\max }$ has shown in the month of April (11.13 hr.) and the the maximum $\mathrm{SH}_{\text {mean }}$ is in the month of March which is more than 7 hours. The maximum of $\mathrm{SH}_{\text {mean }}$ and the $\mathrm{SH}_{\max }$ in the months of March and April may have a strong effect in uprising of temperature which in concern may form any cyclonic event in Patuakhali region.
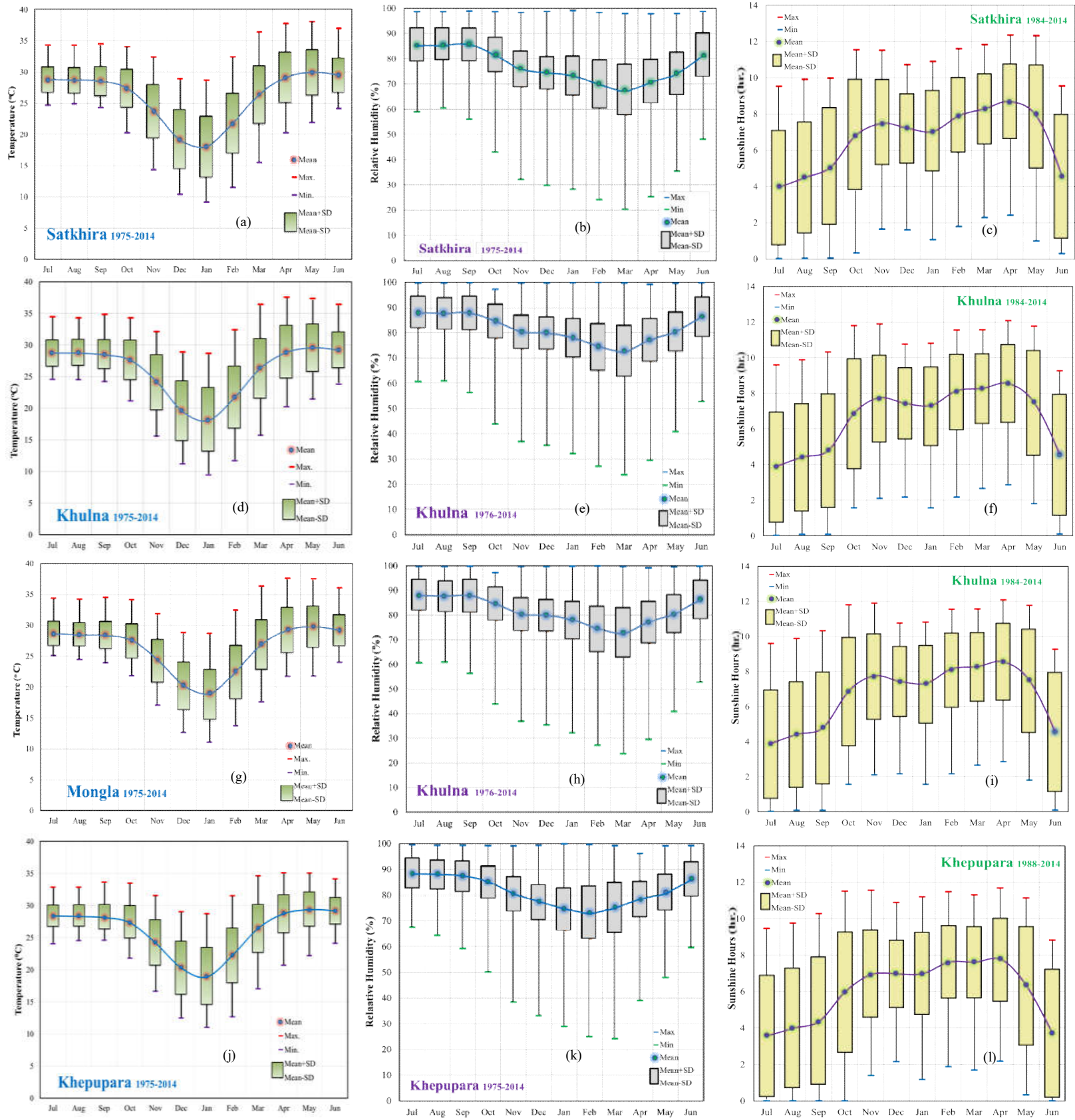

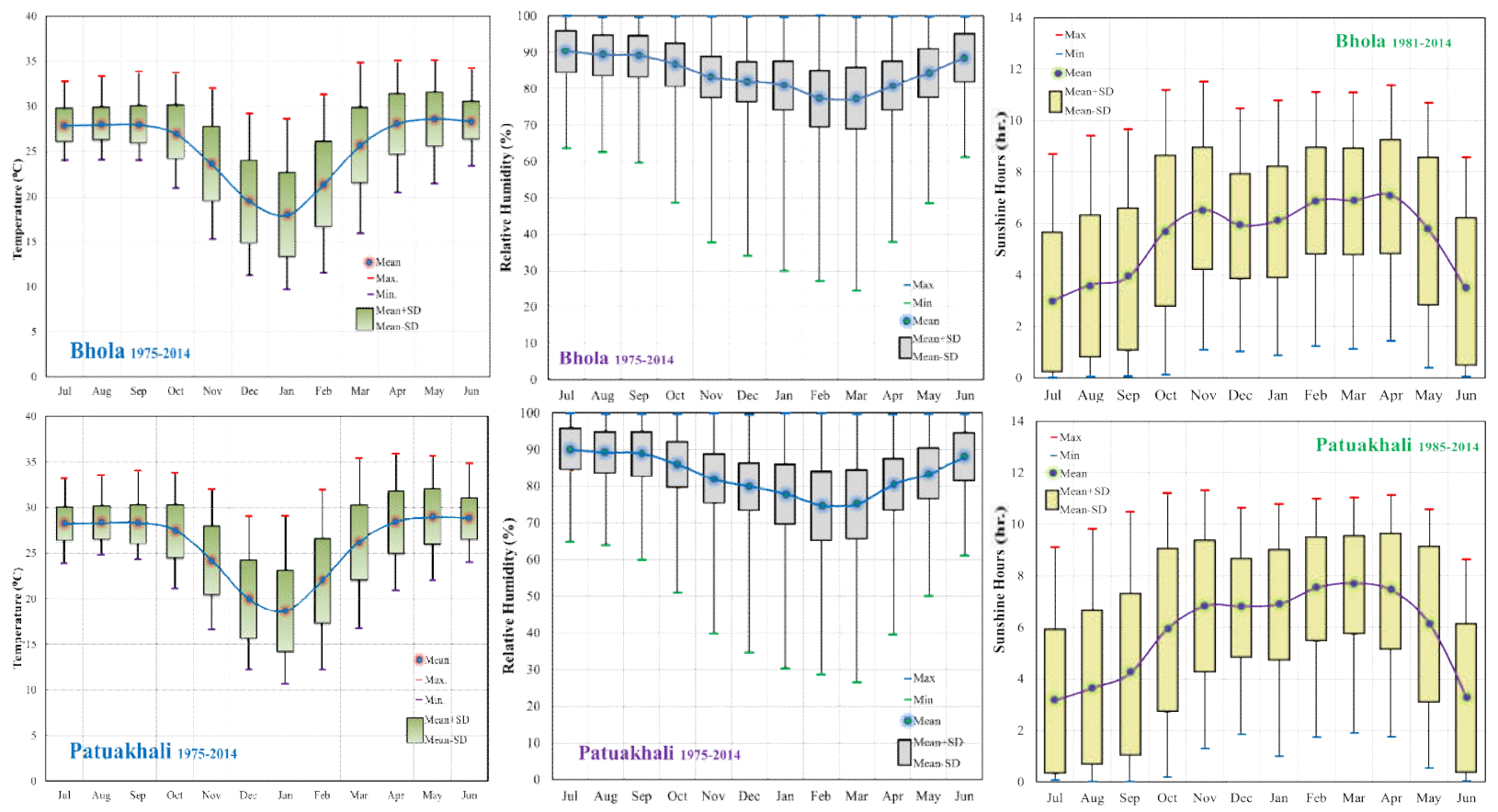

Figure 2. Temperature $\left({ }^{0} \mathrm{C}\right), \mathrm{RH}(\%)$ and $\mathrm{SH}(\mathrm{hr}$.) with maximum, minimum, mean and mean $\pm \mathrm{SD}$ of Satkhira, Khulna, Mongla, Khepupara, Bhola and Patuakhali.

\section{Hatiya}

The $\mathrm{T}_{\max }$ in this area is in the month of May pointing in the Figure 3(a) at $34.39^{\circ} \mathrm{C}$ where the uppermost $\mathrm{T}_{\text {mean }}$ in this area is $28.71^{\circ} \mathrm{C}$ also is in the month of May. The $\mathrm{T}_{\max }$ is ranging from 28 to $35^{\circ} \mathrm{C}$ throughout the year which is not comfortable at all and blamable for unsteady situation. Again the temperature above $28^{0} \mathrm{C}$ is responsible for the formation of cyclone. So the maximum values in this area in the cyclonic period are too high and powerful components for the formation of cyclonic activity in the area. $\mathrm{RH}_{\max }, \mathrm{RH}_{\text {min }}, \mathrm{RH}_{\text {mean }}$ and mean $\pm \mathrm{SD}$ of $\mathrm{RH}$ of Hatiya have shown in the Figure 3(b). Like some of other stations, Hatiya has also shown the Highest $\mathrm{RH}_{\text {mean }}$ value in the month of July which is about $89 \%$ and this highest mean value in the area indicated hot and humid circumstances in that specific month for Hatiya. This high amount of RH also may cause insecure condition in the specific area which in later may form deep depression and ultimately forms cyclone. The trend of $\mathrm{SH}$ in this part has shown in the Figure 3(c). The $\mathrm{SH}_{\max }$ in this area is in the month of May (11.8 hr.) and the highest of $\mathrm{SH}_{\text {mean }}$ is more than 7 hours in the month of November. The $\mathrm{SH}_{\max }$ which has found in the month of May indicating higher amount of temperature in May on such day at Hatiya. This higher amount of temperature may have profound influence to form cyclonic activity in that area.

\section{Chittagong}

$\mathrm{T}_{\text {mean }}, \mathrm{T}_{\max }, \mathrm{T}_{\min }$ and mean $\pm \mathrm{SD}$ of temperature $\left({ }^{0} \mathrm{C}\right)$ has shown in the Figure 3(d). The $T_{\max }$ in this area is $34.33^{\circ} \mathrm{C}$ (in May) and the highest of $\mathrm{T}_{\text {mean }}$ has found in the month of May $\left(28.56^{\circ} \mathrm{C}\right)$. In the post-monsoon season (August to October) the $\mathrm{T}_{\text {mean }}$ is in the range of 27.5 to $28.5^{\circ} \mathrm{C}$ where the $\mathrm{T}_{\max }$ has found about $33.5^{\circ} \mathrm{C}$. Again the range of $\mathrm{T}_{\max }$ throughout the year is about $28-34^{0} \mathrm{C}$. These maximum values indicating strong possibilities for unstable weather conditions in the studied area. Again, sudden rise of temperature like this maximum values may cause deep depression and then may turn into cyclonic storm which may affect the 
whole coastal areas of Bangladesh. RH for the Chittagong area has shown in the Figure 3(e). July has represented the highest $\mathrm{RH}_{\text {mean }}$ pointing about $86 \%$ here in Chittagong. This highest mean value in the area indicated hot and humid circumstances in that specific month in Chittagong. September is also known as the cyclonic month and the high amount of RH showed here also may cause insecure condition in the specific area which in later may form atmospheric low pressure and ultimately forms cyclone.SH for port City Chittagong has shown in the Figure 3(f). It is clearly seen that the maximum of $\mathrm{SH}_{\text {mean }}$ is in the month of March which is more than $8 \mathrm{hr}$. and the $\mathrm{SH}_{\max }$ has found in the month of April (11.60 hr.). The maximum mean of SH and the sudden longest period of $\mathrm{SH}$ in a day of both March and April may have a strong effect in uprising of temperature which in concern may have strong influence to form cyclone in Chittagong region.
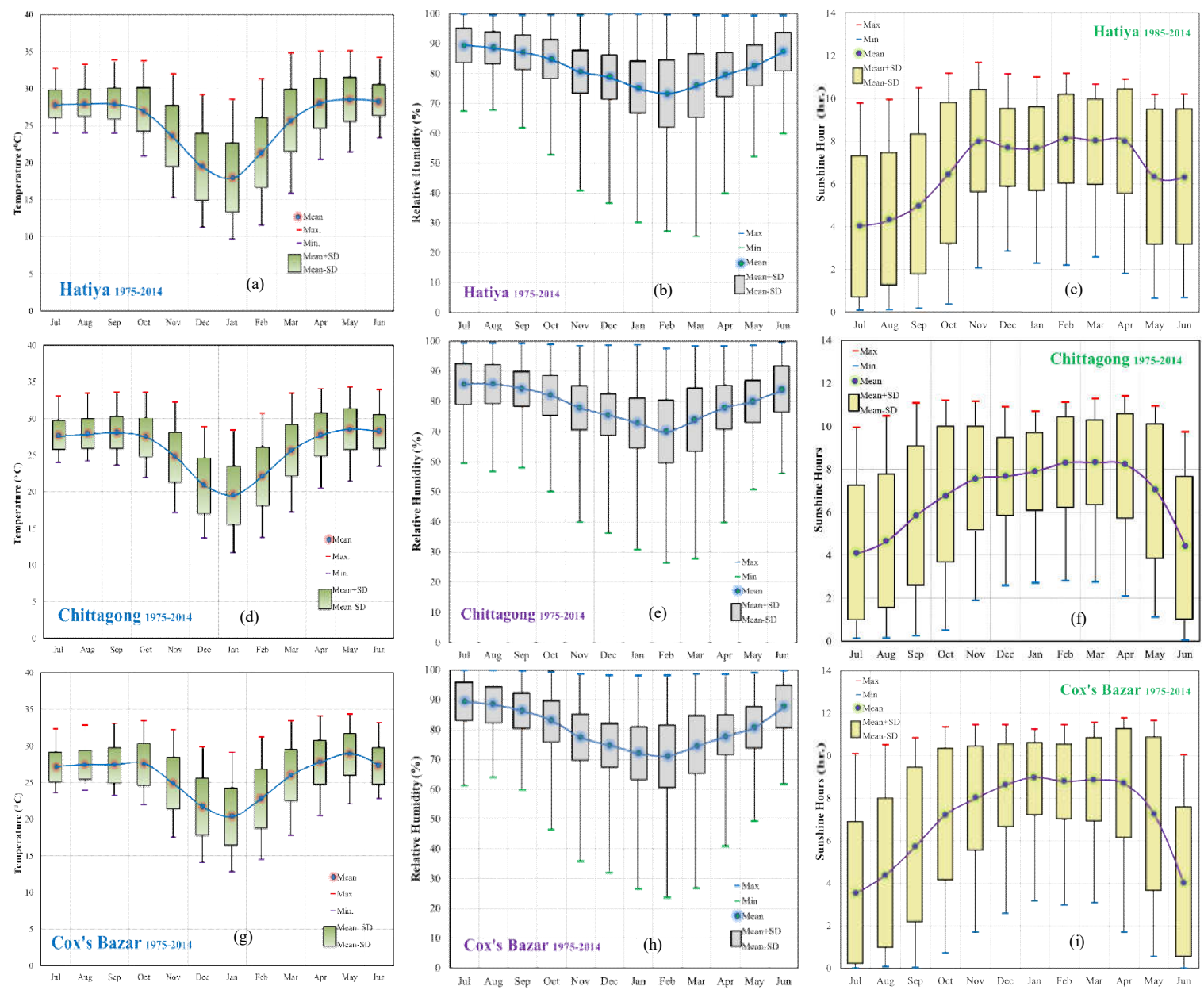

Figure 3. Temperature $\left({ }^{0} \mathrm{C}\right)$, RH (\%) and $\mathrm{SH}(\mathrm{hr}$.) with maximum, minimum, mean and mean $\pm \mathrm{SD}$ of Hatiiya, Chittagong and Cox's Bazar.

\section{Cox's Bazar}

The temperature graph has shown in the Figure $3(\mathrm{~g})$. The graph has shown little bit variations in this area than the other area. The $\mathrm{T}_{\max }$ in this area is in the month of May which is $34.32^{\circ} \mathrm{C}$ and the range of $\mathrm{T}_{\max }$ in this area throughout the year is about 29 to $34.5^{\circ} \mathrm{C}$. The highest $\mathrm{T}_{\text {mean }}$ is about $29^{\circ} \mathrm{C}$ which is in the month of May though in post monsoon cyclonic period 
September and October, the $\mathrm{T}_{\text {mean }}$ is about $26-27^{\circ} \mathrm{C}$ which is very much comfortable and is not suitable enough for creating any unsteady condition. The high amount of temperature in the pre-monsoon period (April and May) indicating unstable disorder at the surrounding area. The trend of RH of Cox's bazar has presented in the Figure 3(h) where it has shown that the $\mathrm{RH}_{\text {max }}$ in this area is in the month of July and August and the point is $99.95 \%$. July has also presented the highest $\mathrm{RH}_{\text {mean }}$ where the $\mathrm{RH}_{\text {mean }}$ is about $89 \%$. This highest mean value in the area showed warm and moist situations in that specific month in Cox's Bazar. This high amount of RH also may cause uncertain situation in the specific area which in later may form deep depression and ultimately forms cyclone.SH for Cox's Bazar area has displayed in the Figure 3(i). The $\mathrm{SH}_{\max }$ in this area is in the month of April which is 11.78 hours This sudden longest period of $\mathrm{SH}$ in a day of April may have a strong effect in uprising of temperature on such day which in concern may form any cyclonic event in Cox's Bazar region.

\section{Ensemble Means}

The Figure 4 represents the comparison of mean values of temperature $\left({ }^{0} \mathrm{C}\right)$ of 16 coastal areas which have been studied here. The figure also represents the average value of temperature of 16 coastal regions of Bangladesh. From the illustration, it is understandably seen that except Satkhira, Khulna, Mongla, Cox's Bazar and Teknaf, the others 11 stations showed almost homogenous starting point from the month of July where the temperature was around $27.5^{\circ} \mathrm{C}$ to $28.5^{\circ} \mathrm{C}$. Among the rests, Satkhira, Khulna and Mongla which have positioned at the last south-western part of Bangladesh and also covered by the Sunder ban have showed the similar starting point where the temperature is ranging from $28.74^{\circ} \mathrm{C}$ to $28.84^{\circ} \mathrm{C}$. In fact, these three areas showed the uppermost $\mathrm{T}_{\text {mean }}$ in the coastal regions of Bangladesh. Cox's Bazar and Teknaf shows little bit lower temperature of the starting point than that of others areas. From July to August, all the stations with their total mean started to rise up indicates little bit rise of temperature in the coastal areas, except Satkhira, Mongla and Khepupara where the temperature is in decreasing trend though the temperature is still higher than the others for these three up to October. From August, the mean is started to fall and drops up to January though for Cox's Bazar and Teknaf, the perceptiveness is dissimilar. In Cox's Bazar, the trend has dropped with a good range in the months from September to October and then rise up again in late October, but from mid-October, the trend has started to fall. For Teknaf, the trend is uprising from its starting point to mid-October and then fall down to January.

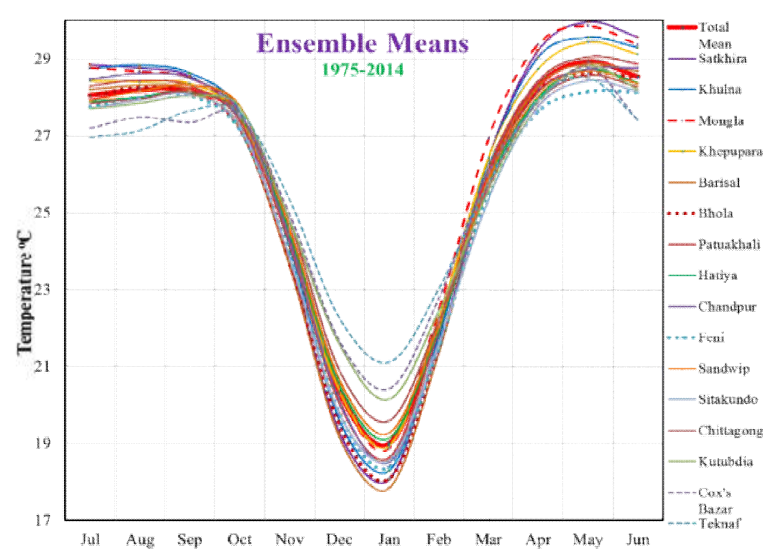

Figure 4. Ensemble means of 16 stations air temperature $\left({ }^{0} \mathrm{C}\right)$ from 1975-2014

So, variations of temperature in this area indicate unstable condition of that surrounding area. From the figure, it has seen that Satkhira, Khulna and Mongla shows relatively higher mean temperature in the month from July to October and from March to June. This situation strongly indicates the possibility of unsteadysituation in that area. Shamsad et al. (2012), Farukh and Baten (2015) reported that increase of $0.5^{\circ} \mathrm{C}$ temperature from August to November may gear up an average of $40 \%$ cyclone activity. Now, if we compare the mean values of Satkhira, Khulna, and Mongla with the total mean value for the two cyclonic period, then we can see that the difference of mean of the areas with their total mean is about $0.5-1^{\circ} \mathrm{C}$ which strongly indicating the possibility of creating 
uncertaincircumstances. Ali (1999), Farukh and Baten (2015) again in their report stated that the months from March to June is second most vulnerable time for the formation of cyclone, because on an around $45 \%$ of cyclone from 1952-2010 has occurred in this time. The scenario in the figure for these months also showing the same indications. The southern-western zone mainly the Sunder ban area is more vulnerable due to its higher temperature scenario than the other stations.

In Figure 5(a), the mean value of RH for 16 stations have represented from where the comparison of the stations is clearly seen along with their total mean value. The result is important as because temperature and RH relates to each other (Lawrence, 2004; Skilling, 2009) and the RH has a good influence on the formation of cyclone (Kaplan and DeMaria, 2003; Emanuel et al., 2004; Hendricks et al., 2010; Kaplan et al., 2010).
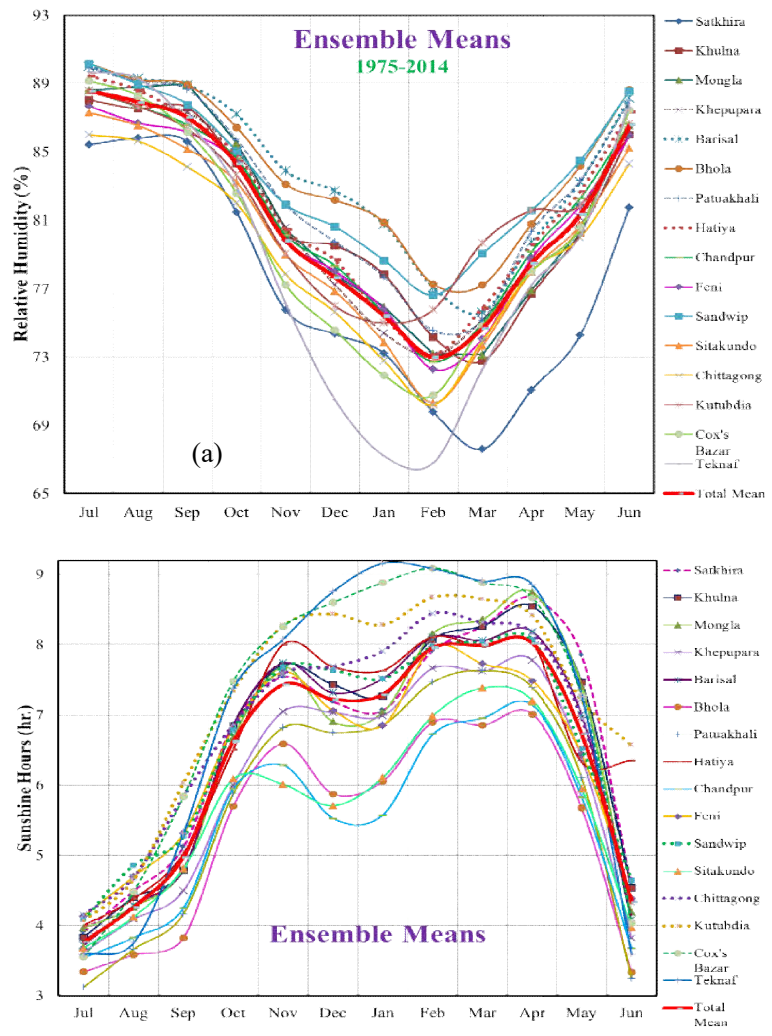

Figure 5. Ensemble means of 16 stations (a) RH (\%) and (b) SH (hr.) from 1975-2014
From the figure it is clearly seen that all the stations show almost similar relationship at its starting point except Chittagong and Satkhira. These two stations show much lower RH than that of others in the month of July. From July to August, the entire trend is decreasing except Satkhira and Mongla and in the following months the entire trend follow similar characteristics except Khulna that showed different characteristics where RH was increasing like Satkhira and Mongla. Then for the preceding months, the mean value has started to fall and continued up to FebruaryMarch. The maximum of total mean has found in the month of July ( $88 \%$ ) which was much higher than the average value in July for whole Bangladesh, recorded $81.78 \%$ (BBS, 2009). In cyclone occurring months specially from August to October, the mean value of the coastal region is on around $84 \sim 88 \%$ and in May to June, the value is about $82-86 \%$ both of which indicate positive sign for the formation of cyclone as $\mathrm{Wu}$ et al. (2012) showed. In fact, Khulna, Mongla, Khepupara and Barisal area are mostly responsible for creating deep depression if the $\mathrm{RH}$ plays any role to the formation of cyclone, as the highest amount of RH has found in this area, though Satkhira showed the lowest amount of RH in these months. In fact, almost every station was not in homogenous trend and showed different characteristics which may have reduced the importance of RH to the formation of cyclone for the coastal areas of Bangladesh.Mean of SH for the 16 stations has been represented in the Figure 5(b). with their total mean which indicating the average mean of the coastal region. The starting point is almost same for all the 16 stations from the month of July ranging from 3.12 to 4.15 hours. Now from this month to November, the time period is increasing for all the 16 stations, except the Sitakundo. From November to April, the lines are not in homogenous trend and there are lots of ups and down in these months in the 16 stations. But from April, the lines have followed similar movement and decreased from this month up to June. SH have not direct effect on the formation of cyclone though there are some indirect consequences of the SH. Because SH 
have positive relationship with the temperature (Matuszko and Weglerczyk, 2014) and temperature have direct effect on the formation of cyclone as it is stated earlier in the temperature part. From the figure, it is clearly seen that in the months of April, the average mean is maximum which indicating the higher amount of temperature in that period. This higher amount of temperature in the following month may cause unstable condition in the area which later may form the unwanted cyclonic events in that area.

\section{Conclusion}

In this study, we mainly tried to find out the temperature, $\mathrm{RH}$ and $\mathrm{SH}$ variations in the coastal area and also their possible effect for the formation of cyclone. Data of this climatic variable was provided by the Bangladesh Meteorological Department (BMD). Then these data were analyzed as per objectives of the study. Temperature in the 16 stations has shown homogenous trend where it has seen that in all the stations the $\mathrm{T}_{\text {mean }}$ is ranging from $18^{\circ} \mathrm{C}$ to $30^{\circ} \mathrm{C}$ in throughout the year where the $\mathrm{T}_{\max }$ is ranging from $28^{0} \mathrm{C}$ to $42^{\circ} \mathrm{C}$. In maximum stations, the $\mathrm{T}_{\max }$ and extreme $\mathrm{T}_{\text {mean }}$ has found in the months of April and May which is a cyclone occurring month. So, extreme temperature in these months may have profound influence for the formation of cyclone. Again, among the coastal areas, Satkhira region has showed the highest $\mathrm{T}_{\text {mean }}$ which makes the area more vulnerable to the formation of cyclone. Again Cox's Bazar has showed increasing trend (different from others) in the month of October which may have influence on the formation of cyclone for this area. $\mathrm{RH}_{\text {max }}$ has mostly found in the post monsoon season may have profound influence on the formation of cyclone. Among the 16 stations, Khulna, Mongla, Khepupara and Barisal area are mostly responsible for creating deep depression if $\mathrm{RH}$ plays any role to the formation of cyclone, as the highest amount of $\mathrm{RH}$ has found in this area. $\mathrm{SH}_{\max }$ has mostly found in the month April where the highest was about $12.08 \mathrm{hr}$. These higher amount of temperature play profound influence in increasing temperature in the studied areas which have direct consequences on cyclone events. So, these variations of temperature, $\mathrm{RH}$ and $\mathrm{SH}$ in these regions could be very useful to study on cyclone eventswhich are a most common phenomenon for the coastal area like Bangladesh.

\section{Acknowledgements}

The authors thank to Bangladesh Meteorological Department (BMD), Agargaon, Dhaka, Bangladesh for providing an immense number of weather datasets. This study was partially supported by the Bangladesh Agricultural University Research System (BAURES) through the research Project No. 2015/67/BAU.

\section{References}

Ali A (1999). Climate change impacts and adaptation assessment in Bangladesh, Clim. Res. 12:109-116.

BBS (2009). Bangladesh Bureau of Statistics, Statistics Division, Ministry of Planning, Statistical Year Book of Bangladesh-2008, BBS, Dhaka, Bangladesh.

Choudhury BJ (1992). Multispectral Satellite Observations for Arid Land Studies. ISPRS J. Photo. Remote Sensing47:101-126.

Emanuel K, DesAutels C, Holloway C, Korty R. (2004). 380 Environmental control of tropical cyclone intensity. J. Atmos. Sci.61: 843-858.

Farukh MA, Baten MA (2015). Temperature Anomaly and Severe Cyclone Events in the southern Coastal regions of Bangladesh, J. Environ. Sci. \& Nat. Res. 8(1): 35-40.

Hendricks EA, Peng MS, Fu B, Li T (2010). Quantifying environ- 394 mental control on tropical cyclone intensity change. Mon. Weather Rev.138: 3243-3271.

Huq S, Karim Z, Asaduzzaman M, Mahtab F (1999). Vulnerability and Adaptation to Climate Change in Bangladesh. Kluwer, Dordrecht, p. 147.

Kaplan J, DeMaria M (2003). Large-scale characteristics of rapidly 404 intensifying tropical cyclones in the North Atlantic basin. Wea. Fore.18(6):10931-108. 
Kaplan J, DeMaria M, Knaff JA (2010). A revised Tropical Cyclone Rapid Intensification Index for the Atlantic and eastern North Pacific Basins. Wea. Fore. 25: 220-241.

Khan MNH (2012). Assessment of Weather Anomalies for Severe Cyclonic Storm Aila in 2009 in Bangladesh. MS Thesis, Department of Environmental Science, Bangladesh Agricultural University.

Kumar A, Done J, Dudhia J, Niyogi D (2011). Simulations of Cyclone Sidr in the Bay of Bengal with a high-resolution model: sensitivity to largescale boundary forcing. Meteorol. Atmos. Phys. 114:123-137.

Lawrence MG (2004). The Relationship between Relative Humidity and the DewpointTemperature in Moist Air Simple Conversion and Applications. Max Planck Institute for Chemistry, Junior Research Group, Department of Atmospheric Chemistry, Postfach 3060, 55020 Mainz, Germany.
Matuszko D, Weglerczyk S (2014). Relationship between sunshine duration and air temperature and contemporary global warming. Int. J. Climatol. 35(12): 3640-3653.

Paul B (2009). Human injuries caused by Bangladesh's Cyclone Sidr: an empirical study. Nat. Hazards 54: 483-495.

Shamsad, Farukh MA, Chowdhury MJR, Basak SC (2012). Sea Surface Temperature Anomaly in the Bay of Bengal. J. Environ. Sci. \& Nat. Res. 5(2): 77- 80 .

Skilling $\mathrm{T}$ (2009). The relationship between relative humidity, temperature and dew point. Chicago Tribune,November 15.

Wisner B, Blaikie P, Cannon T, Davis I (2004). At Risk: Natural Hazards, People's Vulnerability and Disasters $\left(2^{\text {nd }} e d\right)$. New York: Routledge.

Wu L, Su H, Fovell RG, Wang B, Shen JT, Kahn BH, Hristova-Veleva SM, Lambrigtsen BH, Fetzer EJ, Jiang JH (2012). Relationship of environmental relative humidity with North Atlantic tropical cyclone intensity and intensification rate. Geophy. Res. Let.39(1). 